\title{
The Effectiveness of Mathematical Learning Based on WhatsApp Groups Assisted by Student's Worksheet and Motivation
}

\author{
Laras Eprilia Putri \\ Mathematics Education, Universitas Sarjanawiyata Tamansiswa, laraseprilia71@gmail.com \\ Tri Astuti Arigiyati \\ Mathematics Education, Universitas Sarjanawiyata Tamansiswa, tri.astuti@ustjogja.ac.id \\ Irham Taufiq \\ Mathematics Education, Universitas Sarjanawiyata Tamansiswa, irham.taufiq@ustjogja.ac.id
}

\section{ABSTRACT}

This research is a quasi-experimental research that aims to determine whether online learning based on WhatsApp Group with student worksheet assistance is more effective than with-based online learning WhatsApp Group without the assistance of student worksheet in terms of student learning motivation towards mathematics learning outcomes of class VII students at SMP X. The data analysis technique used t-test, prerequisite test in the form of normality test and homogeneity test, Mann-Whitney test, and Kruskal Wallis test. The result of this study is that online learning based on WhatsApp Group with the assistance of student worksheet is as effective as online learning based on WhatsApp Group without the assistance of worksheet and the mathematics learning outcomes of students with high motivation are better than students with moderate and low motivation.

Keywords: online learning, WhatsApp Group, student worksheet, Motivation.

\section{ABSTRAK}

Penelitian ini merupakan penelitian eksperimen semu yang bertujuan untuk mengetahui apakah pembelajaran daring berbasis WhatsApp Group berbantuan Lembar Kerja Peserta Didik (LKPD) lebih efektif dengan pembelajaran daring berbasis WhatsApp Group tanpa berbantuan LKPD yang ditinjau dari motivasi belajar siswa terhadap hasil belajar matematika siswa kelas VII di SMP X. Sampel dalam penelitian ini diambil dengan teknik cluster random sampling. Teknik pengumpulan data menggunakan teknik tes berupa post-test, dokumentasi untuk nilai pre-test dan teknik non-tes berupa angket motivasi belajar. Teknik analisis data menggunakan uji-t, uji prasyarat berupa uji normalitas dan uji homogenitas, uji mannwhitney, dan uji kruskal wallis. Hasil penelitian ini adalah pembelajaran daring berbasis WhatsApp Group berbantuan LKPD sama efektifnya dengan pembelajaran daring berbasis WhatsApp Group tanpa berbantuan LKPD dan hasil belajar matematika siswa dengan motivasi tinggi lebih baik dari siswa yang memiliki motivasi sedang dan rendah.

Kata Kunci: pembelajaran daring, WhatsApp Group, LKPD, Motivasi

\section{INTRODUCTION}

Education is a conscious and planned effort to create a learning atmosphere and learning process that students actively develop their potential to have spiritual, religious, self-control, personality, intelligence, noble character, and skills needed by themselves, society, nation and state (Sutrimo, Kamid \& Saharudin, 2019). Learning will never be separated in human life because every 
human will have problems that require to solve it and require humans to learn. Learning activities are an educational process in schools. Thus, it can be interpreted that the success or failure of an education depends on student learning activities which include cognitive, affective and psychomotor aspects (Khikmiyah, 2020; Sidiq, 2016).

The learning process is currently experiencing many obstacles. One of them is the weak process of learning activities caused by the corona virus disease 2019 (Covid-19) pandemic. The Covid-19 pandemic has hit all countries in the world, including Indonesia. Covid-19 is an infectious disease, which means it can spread directly or indirectly from one person to another. This virus attacks the respiratory system such as the nose, throat, and lungs. In handling the outbreak, the lack of vaccines and cures for Covid-19 patients and the limited personal protective equipment for health workers have made the government implement strict policies to break the chain of the spread of Covid-19. One way to break the chain of the spread of Covid-19 is to limit public interaction which is applied by the term physical distancing. However, the physical distancing policy can hamper the growth rate of various fields of life, both in the economic, social and educational fields (Mustakim, 2020; Yulia, Buyung \& Relawati, 2018; Fuady, 2017). In the field of education, the government moved the teaching and learning process at school to be at home by implementing a work from home (WFH) policy. This decision made many parties, both teachers and students nervous. Likewise, SMP X has to implement an online learning system.

According to Hutami \& Anindtya (2020), As a teacher, in an effort to carry out the learning process during this pandemic, it needs to be done online or in a network (online). The use of online media or multimedia-based media is one solution to carry out the learning process during this pandemic. One of the online media used is WhatsApp Group as was done at SMP X. The learning process at SMP $X$ also uses offline learning to collect assignments that have been given by the teacher through WhatsApp Group. WhatsApp has various functions including sending messages, group chats, sharing photos, videos and documents. Online learning through WhatsApp Groups can help teachers provide material in the form of Power Point, Portable Document Format (PDF), short videos, or reading materials, while students can send work and discuss questions and answers about the material presented (Hutami \& Anindtya, 2020; Dewi, Isnani, \& Ahmadi, 2019; Suryadi , 2018). However, the implementation of the online learning process has several obstacles, one of which is in mathematics.

At SMP X grade 7th, $77 \%$ of students still consider mathematics a difficult subject because the characteristics of mathematics are abstract, logical, systematic, and full of confusing symbols and formulas. This is based on the acquisition of the odd semester math mid-semester assessment score for the 2020/2021 academic year which is still less than the KKM, which is less than 64. Students complain because the delivery of material is easier to understand if the teacher explains it directly rather than through online learning. This causes students to not be optimal in understanding the material, resulting in reduced student motivation in learning mathematics (Apriyani \& Sujadi, 2015; Dewi, 2020; Auliya, 2016).

In online learning using WhatsApp Groups, it turns out that it has not been able to help the learning process run optimally. Students have not optimally received the learning delivered by the 
teacher. Therefore, there is a need for learning tools that can be used to support current online learning activities (.Lanya \& Aini, 2019; Hamidah, Haryani,\& Wardani, 2018). One of the learning tools that are in accordance with current conditions is the Student Worksheet. In addition to supporting online learning, Student worksheet is used to increase student interest in learning and make it easier for students to think so that they can improve learning outcomes and student motivation (Yustianingsih, Syarifuddin \& Yerizon, 2017). Student worksheet contains tasks that are tailored to the basic competencies and learning objectives that must be achieved. Motivation in the mathematics learning process is very necessary and teachers must always provide motivational motivation in the learning process because it will be useful in the success of the learning process that will be carried out (Sirri, \& Lestari, 2020; Sholikhakh, Pujiarto, \& Suwandono, 2019; Saharsa, Qaddafi, \& Baharuddin, 2018).

Based on this background, the researcher will conduct a study entitled "The Effectiveness of Online Learning Based on WhatsApp Groups Assisted by Student worksheet Judging from the Motivation of grade 7th Students at SMP X".

\section{METHOD}

The type of research used in this research is a quasi-experimental research. According to Sugiyono (2013) quasi-experimental research is defined as a research method used to find the effect of certain treatments on others under controlled conditions. This study aims to provide treatment to the research sample, then researchers want to know which one is more effective in each treatment. The population of this study was all 7th grade students of SMP X for the 2020/2021 academic year, totaling 219 students. The samples used in this study were grade VII D and grade VII E which were selected using cluster random sampling technique. Grade VII D with 31 students as the control class and class VII E with 32 students as the experimental class. The experimental class is a class that is given treatment, namely online learning based on WhatsApp Group assisted by Student worksheet, while the control class is a class that does not receive treatment, namely online learning based on WhatsApp Group without the assistance of Student worksheet. This research was conducted in the odd semester of the 2020/2021 academic year.

The data collection technique used in this study is a test technique in the form of a post-test, documentation for pre-test scores and a non-test technique in the form of a student learning motivation questionnaire. The data that has been collected is recapitulated and analyzed and then concluded. The instruments used in this research are learning outcomes tests and student motivation questionnaires. Instrument testing has a very important position because the data is a description of the variables studied and as a means of proof. In a study there are basic requirements of research instruments in the form of validity and reliability tests. In this study, the pre-test used to measure the students' initial abilities used the results of the Odd Semester Middle Assessment, while the posttest used the used test, which means that the instrument was directly tested on the sample, then directly tested for validity, level of difficulty, discriminatory power, and reliability. To test the validity of both the learning outcomes test and motivation questionnaire, the correlation formula used is the Pearson Product Moment formula. The correlation results were then consulted with the table $r$ 
product moment at a significant level of $5 \%$. After being consulted, it can be seen whether the instrument used is valid or not. If $r_{\text {test }} \geq r_{\text {table }}$ then the instrument is said to be valid (Arikunto, 2013). The value $r_{\text {table }}$ for the number of students 63 is 0,248 . Based on the test results of the validity of the items on the student's mathematics learning outcomes test of 15 items, all items are valid. Meanwhile, in the motivational questionnaire validity test of 20 items, only 19 items were valid.

Difficulty level $(P)$ is used to determine the level of difficulty of the question whether the question has difficult, medium, or easy criteria. In this study, the difficulty index criteria used were medium and easy. Based on the results of the test item difficulty level on the student learning outcomes test of 15 items, there is 1 item with easy criteria, namely number 1 and there are 14 items with moderate criteria, namely item numbers $2,3,4,5,6,7,8,9,10,11,12,13,14,15$. Distinctive Power (DP) is used to determine the ability of the items to be able to distinguish between students who have mastered the material being tested and students who have not mastered the material being tested. According to Arifin(2012) the calculation of discriminatory power is a measurement of the extent to which an item can distinguish students who have mastered competence from students who have not mastered competence. Questions that are good and can be used are questions that do not have bad or very bad distinguishing power. In this study the different power criteria used are. Based on the results of the calculation of the differentiating power of the 15 items, there is 1 item with bad criteria, namely number 1 but 4 items with good criteria, namely number 2,7, 8, 11; 10 items with moderate criteria are $3,4,5,6,9,10,12,13,14,15$. From the calculation of the differentiating power of the item, there are 14 items that are eligible to be used and 1 item that has failed.

Based on the results of validity test, difficulty level and differentiating power of 14 test items are feasible to use. Then reliability $r_{\text {tabel }}=0,398$ and $n=14$ can be write $r_{\text {hitung }} \geq r_{\text {tabel }}$ i.e $0,72621 \geq 0,398$. It means that the test items are reliable with high reliability criteria. As for the reliability of the student learning motivation questionnaire with $n=19$, then $r_{\text {table }}=0,483$. So it can be concluded that $0,853 \geq 0,483$ the questionnaire on student learning motivation is reliable with very high reliability criteria. The tendency of students' mathematics learning outcomes was analyzed descriptively by looking for the highest score, lowest score, standard deviation, and average of each variable and then by comparing the average value of student learning outcomes with five scale conversion criterias, namely very high, high, medium, low and very low. Meanwhile, the tendency of students' mathematics learning outcomes based on motivation was analyzed descriptively by looking for the highest score, lowest score, standard deviation, and average of each variable and then by comparing the score of the student learning motivation questionnaire with three scale conversion criteria, namely high, medium and low. The prerequisite test is in the form of normality test and homogeneity test, while the data analysis test or hypothesis test uses the Mann-Whitney test, and the Kruskal Wallis test.

\section{RESULT AND DISCUSSION}

The results of this study indicate that students' mathematics learning outcomes using online learning based on WhatsApp Group assisted by Student worksheet are included in the moderate criteria, which can be seen from the average value of mathematics learning outcomes of 54 which 
lies in the range $41,665<\bar{x} \leq 58,335$. Meanwhile, online learning based on WhatsApp Group without Student worksheet assistance is also included in the moderate criteria, which can be seen from the average value of mathematics learning outcomes of 51 which lies in the range $41,665<\bar{x} \leq 58,335$.

Meanwhile, for students' mathematics learning outcomes based on learning motivation, the data on students' mathematics learning outcomes based on learning motivation is known that: (1) the average score of the motivational questionnaire of students who have high motivation is 66. (2) the average score of the motivational questionnaire of students who have motivation medium amounted to 55,638. (3) the average score of the student motivation questionnaire who has low motivation is 47,428 . It can be concluded that students who have high learning motivation have better mathematics learning outcomes than students who have moderate and low learning motivation. Students who have moderate motivation have better mathematics learning outcomes than students who have low learning motivation.

Before conducting the data analysis test, the researcher conducted a balance test, normality test and homogeneity test. The balance test is used to determine whether the two classes, namely the experimental class and the control class, are in balance or not. The data used to determine the average balance is the value of the pre-test conducted at the beginning of the meeting both in the experimental class and the control class. The pre-test scores used in this study were obtained from the results of the Mid-Semester Mathematics Odd Assessment scores. The test statistic used for the balance test is the t test, namely the experimental class and the control class are said to have the same average and are balanced if $t_{\text {count }}<t_{\text {table }}$. Based on the results of calculations with $t_{\left(\frac{\alpha}{2} ; n_{1}+n_{2}-2\right)}=1,9996$ obtained $t_{\text {count }}<t_{\text {table }}$ is $0,68287<1,9996$ it means that the experimental class and the control class have the same average and are balanced. So it can be concluded that the two classes have a balanced initial ability.

After the initial balance test for the two classes was carried out, then continued with normality and homogeneity tests for data on initial abilities and students' mathematics learning outcomes. To test for normality using the Kolmogorov-Smirnov test with a significance level of $5 \%$. If probability $(\mathrm{sig})>0,05$ then $H_{0}$ is rejected, which means the sample comes from a normally distributed population (Siregar, 2017). As for the homogeneity test by looking at the Test of Homogeneity of variances, if $p>\alpha$ then the sample has the same or homogeneous variance

Based on the data from the initial ability normality test above, it shows that Sig. in both of class, Sig. $>0,05$, i.e. $0,200>0,05$, then $\mathrm{HO}$ is accepted, meaning that the initial ability data for the experimental class and the control class are normally distributed. Meanwhile, based on the data from the initial ability homogeneity test, the value of $p>\alpha$ i.e $0,9777>0,05$, meaning that the experimental class and control class have the same variance (homogeneous) in other words the experimental class and control class have the same initial ability.

Table 1. Resume of normality test of student's mathematical test result

\begin{tabular}{lcl}
\hline \multicolumn{1}{c}{ Groups } & Sig. & \multicolumn{1}{c}{ Conclusion } \\
Experiment class $\left(A_{1}\right)$ & 0,011 & Abnormal \\
Controll class $\left(A_{2}\right)$ & 0,000 & Abnormal \\
HIngh motivation $\left(B_{1}\right)$ & 0,200 & Normal \\
\hline
\end{tabular}




\begin{tabular}{ccc}
\hline Groups & Sig. & Conclusion \\
Moderate motivation $\left(B_{2}\right)$ & 0,000 & Abnormal \\
Low motivation $\left(B_{3}\right)$ & 0,041 & Abnormal \\
\hline
\end{tabular}

From the table 1, it can be seen that only students' mathematics learning outcomes based on high motivation come from normally distributed populations. Therefore, it is not necessary to test the homogeneity of variance. (Herlina, 2019; Mustami, Paridjo, \& Utami,, 2020).

Based on the results of the normality test of learning outcomes based on the learning method that the sample from the population data is not normally distributed, then the hypothesis testing is carried out by testing two means using the Mann-Whitney test. In this study, the Mann-Whitney test used was Monte Carlo with a significance level of $\alpha=0,05$ (Herlina, Tjahjeni., et.all. 2019).

The statistical hypothesis is formulated as follows:

$H_{A 0}: \quad \mu_{E} \leq \mu_{K}$,

(WhatsApp Group-based online learning assisted by Student worksheet is no better than WhatsApp Group-based online learning without Student worksheet -assisted).

$H_{A 1}: \quad \mu_{E}>\mu_{K}$

(WhatsApp Group based online learning assisted by Student worksheet is better than WhatsApp Group based online learning without Student worksheet assistance).

The criteria of test are if Sig.(2-tailed) $>0,05$ then $H_{A 0}$ is accepted and if Sig.(2-tailed) $\leq$ 0,05 then $H_{A 0}$ is rejected. Based on the data of two average test mathematics learning outcomes with the method, it shows that Sig. $>0,05$ yaitu 0,676 $>0,05$ then $H_{0}$ is accepted, which means that online learning based on WhatsApp Group assisted by Student worksheet is not better than online learning based on WhatsApp Group without being assisted by Student worksheet. It is caused by student did not learn seriously so most of students did not understand to the material. Communication between student and teacher in whatsApp group is not two direction so student did not follow teacher's instructure to do student worksheet. In other words, online learning based on WhatsApp Group is as effective as online learning based on WhatsApp Group without the assistance of Student worksheet. However, when viewed based on the average learning outcomes of mathematics with online learning based on WhatsApp Group assisted by Student worksheet, it is higher than WhatsApp Group without assistance from Student worksheet, namely $54>51$. This is because students are not used to using online learning methods based on WhatsApp Groups assisted by Student worksheet and still feel foreign to adapt to these learning methods even though both methods are both in online learning (Anjani, Ratnamulyani \& Kusumadinata, 2018; Yensi, 2020)

Based on the results of the normality test of learning outcomes based on learning motivation that the sample from the population data is not normally distributed, then the hypothesis testing is carried out by using a two-mean test using the Kruskal-Wallis $\mathrm{H}$ test. In this study, the Kruskal-Wallis $\mathrm{H}$ test used was Monte Carlo with a significance level $\alpha=0,05$.

The statistical hypothesis is formulated as follows:

$H_{B 0}: \quad \mu_{1}=\mu_{2}=\mu_{3}$

(There is no difference in the average learning outcomes of mathematics based on the level of motivation).

$H_{B 1}$ : (there is at least one difference in the average learning outcomes of mathematics based on the level of motivation) 
The criteria of test are if Sig. $>0,05$ then $H_{B 0}$ is accepted, and if Sig. $\leq 0,05$ then $H_{B 0}$ is rejected. Based on data of two average test mathematics learning outcomes with learning motivation, it shows that Sig. $>0,05$ i.e $0,469>0,05$ then $H_{B 0}$ is accepted, which means that there is no difference in the average learning outcomes of mathematics based on the level of learning motivation. However, there are differences in learning outcomes between students who have high motivation and student learning outcomes who have moderate motivation with average learning outcomes 63,1 >51,109 but not significant. And learning outcomes between students who have moderate motivation and student learning outcomes who have low motivation with average learning outcomes 51,109 > 45,00 but not significant.

This happened because of the time of giving the questionnaire at the end of the lesson and through the Google Form link because it was online. So that when filling out the questionnaire, many students who filled out the questionnaire were not careful in reading the statement, and there were even students who just filled it out randomly. In addition, researchers are less careful in the division of learning time (Kusuma \& Hamidah, 2020; Darmalaksana, 2020).

\section{CONCLUSION}

Based on the results of research and discussion, it can be concluded that online learning based on WhatsApp Group is as effective as online learning based on WhatsApp Group without the assistance of Student worksheet. The tendency of mathematics learning outcomes for grade VII students of SMP $X$ who are taught using online learning based on WhatsApp Group and online learning based on WhatsApp Group without the help of Student worksheet are included in the moderate criteria. The results of learning mathematics are relatively the same when viewed from the motivation to learn. When viewed from the average value based on learning motivation, it can be concluded that students who have high learning motivation have better mathematics learning outcomes than students who have moderate and low learning motivation. Students who have moderate motivation have better mathematics learning outcomes than students who have low learning motivation. Recommendation for next research, researcher research google classroom,google meet, etc. Beside that researcher use module.

\section{ACKNOWLEDGEMENT}

The authors would like to thank to Mathematics Education study program and LP2M UST that fund this research.

\section{REFERENCES}

Anjani, A., Ratnamulyani, I. A., \& Kusumadinata,A .(2018). Penggunaan Media Komunikasi Whatsapp terhadap Efektivitas Kinerja Karyawan. Jurnal Komunikasitio, Volume 4 nomor 1

Apriyani, D \& Sujadi, A.(2015). Efektivitas Pembelajaran Matematika dengan Pendekatan Matematika Realistik Indonesia Terhadap Kemampuan Motivasi Belajar Siswa Kelas VII SMP Negeri 3 Pandak Tahun 2013/2014. Jurnal Pendidikan Matematika Vol, 3 Nomor 3. HIm. 318.

Arifin, Z. (2012). Penelitian Pendidikan: Metode dan Paradigma Baru. Bandung: PT Remaja Rosdakarya.

Arikunto, S. (2013). Prosedur Penelitian : Suatu Pendekatan Praktik. Jakarta: Rineka Cipta.

Auliya, R. N.(2016). Kecemasan Matematika dan Pemahaman Matematis. Jurnal Ilmiah Pendidikan 
MIPA Vol, 6 Nomor 1, HIm, 11-22.

Darmalaksana, W., et al.(2020). Analisis Pembelajaran Online Masa WFH Pandemic Covid-19 sebagai Tantangan Pemimpin Digital Abad 21.1-12.

Dewi, A. S., Isnani, I., \& Ahmadi, A.(2019). Keefektifan Model Pembelajaran STAD Berbantuan Media Pembelajaran Terhadap Sikap dan Kemampuan Pemecahan Masalah Matematika. JIPMat, Volume 4 nomor 1

Dewi, W. A. F.(2020). Dampak Covid-19 terhadap implementasi pembelajaran daring di Sekolah Dasar. Edukatif: Jurnal IImu Pendidikan, Volume 2 Nomor 1, halaman 55-61.

Fuady, A (2017). Berfikir Reflektif Dalam Pembelajaran Matematika. JIPMat, 1(2), 104-112.

Hamidah, N, Haryani, S dan Wardani, S. (2018). Efektivitas Lembar Kerja Peserta Didik Berbasis Inkuiri Terbimbing Untuk Meningkatkan Hasil Belajar Siswa. Jurnal Inovasi Pendidikan Kimia. Volume 12 Nomor 2

Herlina, T dkk. (2019). Meningkatkan Kemampuan Pemahaman Matematik Siswa SD Melalui Metode Diskusi Kelompok. Journal of Elementary Education (Vol, 2 Nomor 2). HIm. 66-70.

Hutami, M. S \& Nugraheni, A.S. (2020). Metode Pembelajaran Whatsapp Group Sebagai Antisipasi Penyebaran Covid-19 pada Anak Usia Dini di TK ABA Kleco Kotagede. Jurnal Penelitian Dalam Bidang Pendidikan Anak Usia Dini (Vol, 9 Nomor 1). HIm. 127.

Khikmiyah, F. (2020). Implementasi Web Live Worksheet Berbasis Problem Based Learning Dalam Pembelajaran Matematika. Pedagogy. Volume 6 Nomor 1

Kusuma, J. W., \& Hamidah, H. (2020). Perbandingan Hasil Belajar Matematika dengan Penggunaan Platform Whatsapp Group dan Webinar Zoom dalam Pembelajaran Jarak Jauh pada Masa Pandemik Covid-19. Jurnal IImiah Pendidikan Matematika. Volume 5 No. 1

Lanya, H \& Aini, S.D. (2019). Efektifitas Model Pembelajaran Osborn Dengan Teknik Brainstorming Pada Mata Kuliah Metode Numerik Jurnal Indomath.vol 2 no. 1

Mustakim. (2020). Efektivitas Pembelajaran Daring Menggunakan Media Online Selama Pandemi Covid-19 pada Mata Pelajaran Matematika, Journal of Islamic Education Vol, 2 Nomor 3, HIm 2-3.

Mustami, S. S., Paridjo, \& Utami, W. B., (2020). Efektivitas pembelajaran melalui Whatsapp grup terhadap kemampuan pemecahan masalah matematika, Jurnal Pendidikan Surya Edukasi (JPSE), Volume 6 Nomor 2 Halaman 175-180

Saharsa, U., Qaddafi, M., \& Baharuddin. (2018). Efektivitas penerapan Model Pembelajaran Problem Based Learning Berbantuan Video Based Laboratory Terhadap Peningkatan Pemahaman Konsep Fisika. Jurnal Pendidikan Fisika , 6 (2), 57-64.

Sholikhakh, R. A., Pujiarto, H., \& Suwandono, S. (2019). Keefektifan Model Pembelajaran Problem Based Learning terhadap Minat dan Prestasi Belajar Matematika. Journal of Medives: Journal of Mathematics Education IKIP Veteran Semarang, 3(1), 33-39.

Sidiq, R. (2016). Pemanfaatan Whatsapp Group Dalam Pengimplementasian Nilai-Nilai Karakter Pancasila Pada Era Disrupsi. 5(1), 145-154.

Sirri, E. L \& Lestari, P. (2020). "Implementasi Edpuzzle Berbantuan Whatsapp Group sebagai Alternatif Pembelajaran Daring pada Era Pandemi. Jurnal Pendidikan Matematika Indonesia (Vol, 5 Nomor 2). HIm 68.

Sugiyono. (2013). Metodologi Penelitian Pendidikan : Pendekatan Kuantitatif, Kualitatif, dan R\&D. Bandung: Alfabeta.

Suryadi. E, dkk. (2018). Penggunaan Sosial Media WhatsApp dan Pengaruhnya Terhadap Disiplin Belajar Peserta Didik Pada Mata Pelajaran Pendidikan Agama Islam (Studi Kasus di SMK Analis Kimia YKPI Bogor). Jurnal Pendidikan Islam. Vol. 7. No. 1.

Sutrimo, Kamid \& Saharudin. (2019). LKPD Bermuatan Inquiry dan Budaya Jambi: Efektivitas dalam Meningkatkan Kemampuan Berpikir Kreatif Matematis. Jurnal Indomath Vol 2. No. 1

Yensi, N. A, (2020). Efektifitas Pembelajaran Statistika Matematika melalui Media Whatsapp Group Ditinjau dari Hasil Belajar Mahasiswa (Masa Pandemik Covid 19). Jurnal Pendidikan Matematika Raflesia. Volume 5 Nomor 2

Yulia, S., Buyung, B., \& Relawati, R. (2018). Pengembangan Lembar Kerja Siswa (LKS) Berbasis Problem Based Learning Pada Materi Bilangan di Kelas VII SMP Negeri 22 Kota Jambi. PHI: Jurnal Pendidikan Matematika, 2(1), 192-204

Yustianingsih, R, Syarifuddin, H \& Yerizon. (2017). Pengembangan Perangkat Pembelajaran Matematika Berbabsis Problem Based Learning (PBL) Untuk Meningkatkan Kemampuan Pemecahan Masalah Peserta Didik Kelas VIII. Jurnal Nasional Pendidikan Matematika (Vol, 1 Nomor 2). HIm. 265. 